\title{
PDE5 Inhibitors in Type 2 Diabetes Cardiovascular Complications
}

\author{
Federica Barbagallo $₫$, Federica Campolo, Edoardo Franceschini, Elena Crecca, Riccardo Pofi $₫$, \\ Andrea M. Isidori and Mary Anna Venneri * (D) \\ Department of Experimental Medicine, Sapienza University, 00161 Rome, Italy; \\ federica.barbagallo@uniroma1.it (F.B.); federica.campolo@uniroma1.it (F.C.); \\ edoardo.franceschini@uniroma1.it (E.F.); elena.crecca@uniroma1.it (E.C.); riccardo.pofi@uniroma1.it (R.P.); \\ andrea.isidori@uniroma1.it (A.M.I.) \\ * Correspondence: maryanna.venneri@uniroma1.it
}

Received: 31 July 2020; Accepted: 20 October 2020; Published: 29 October 2020

\begin{abstract}
Pharmacological inhibition of Phosphodiesterase type 5 (PDE5) proved its efficacy treating several pathological conditions, such as erectile dysfunction and pulmonary hypertension. Nowadays, its benefits on cardiovascular diseases are well documented, particularly in the treatment of type 2 diabetes (T2DM)-related cardiovascular complications. In this context, treatment of T2DM with PDE5 inhibitors, such as sildenafil, tadalafil or vardenafil ameliorates endothelial dysfunction both in patients and animal models through an augmented flow mediated dilation rate and an up-regulation of endothelial markers; it also reduces the inflammatory state by down-regulating inflammatory cytokines expression and improves diabetic cardiomyopathy and ischemia-reperfusion injury mainly through the activation of NO-cGMP-PKG pathway. The present review summarizes the state of art on PDE5 inhibition in the treatment of cardiovascular complications in T2DM.
\end{abstract}

Keywords: PDE5i; type 2 diabetes; cardiovascular complications

\section{Introduction}

Phosphodiesterases (PDEs) comprise a class of enzymes that hydrolyze cyclic adenosine $3^{\prime}, 5^{\prime}$-monophosphate (cAMP) and/or cyclic guanosine $3^{\prime}, 5^{\prime}$ - monophosphate (cGMP) into their inactive form $5^{\prime}$-AMP or GMP, regulating not only the intensity but also the spatial and temporal duration of related signaling pathways and intracellular responses. The PDE superfamily embraces 11 gene families, categorized on the basis of their sequence similarity, mode of activation and the affinity for the second messengers. The 21 encoded genes, due to the existence of various transcriptional initiation sites and/or different alternative spliced mRNA, give rise to more than 100 isoforms that display tissue, cellular and subcellular specific expression [1].

PDE1, PDE2 and PDE3 possess dual-specificity esterase activity since they hydrolyze both cAMP and cGMP; PDE4 and PDE8 specifically hydrolyze cAMP while PDE5 and PDE9 breakdown specifically cGMP [2]. cGMP is synthetized by the guanylyl cyclases (GCs): the soluble GC (sGC) activated by nitric oxide (NO) and by the membrane-bound particulate GC (pGC) induced by natriuretic peptides (NPs).

The human cardiovascular system expresses most of the PDEs and, in particular, PDE1-5, PDE8, PDE9 and PDE10 [3]. In this system, NO is endogenously generated by endothelial NO synthase (eNOS) and, upon physiological stimulus, paracrinally promotes sGC activity in the contiguous vascular smooths muscle cells (VSMCs). The consequent elevation of cGMP promotes the activation of protein kinase G (PKG) that phosphorylates a broad range of substrates such as vasodilator-stimulated phosphoprotein (VASP) [4], regulatory myosin-binding subunit of 
myosin phosphatase [5], calcium-activated maxi $\mathrm{K}+(\mathrm{BKCa})$ channels [6] and inositol trisphosphate receptor-associated cGMP-kinase substrate (IRAG) [7]. The result is a decrease in intracellular calcium and vasodilation. NPs hormones, comprising the Atrial-NP (ANP), the Brain NP (BNP) and C-type NP (CNP) display diuretic, natriuretic, and hypotensive actions, regulating blood volume and pressure [8]. In cardiomyocytes, CNP exerts a PKG-mediated negative inotropic and positive lusitropic effects, while ANP and BNP or NO had no effect on contractility [9].

PDE5 is expressed ubiquitously and three alternative splicing variants of this gene which differ in the $N$-terminus have been characterized both in humans and mice [10,11].

The pivotal role of PDE5 in the regulation of smooth muscle tone in the vasculature is well established [12] and PDE5 inhibitors, such as sildenafil, vardenafil, and tadalafil, are broadly used as first line treatment options in erectile dysfunctions and pulmonary hypertension [13]. Even if PDE5 protein expression in normal and diseased heart is still an open issue due to the variability of the results obtained on cardiomyocytes and heart samples [14-16], PDE5 activity has been demonstrated to account for the $22 \%$ of the cytosolic cGMP-hydrolytic activity in normal heart reaching $40 \%$ in a mouse model of heart failure [17]. Indeed, PDE5 inhibitors have been successfully used as antihypertrophic and cardioprotective agents [18-20]. The combined search PDE5 inhibitors/cardiovascular disease turns out more than 170 clinical trials (http://www.clinicaltrials.gov) focused on the potential benefits of PDE5 in cardiovascular system in several pathologies (Table 1).

Table 1. Main findings of Randomized Clinical Trial that assessed PDE5i effects on cardiovascular disease.

\begin{tabular}{|c|c|c|c|}
\hline Condition & Patients & $\begin{array}{l}\text { Patients with } \\
\text { T2DM }(N)\end{array}$ & Main Research Finding \\
\hline \multirow{3}{*}{$\begin{array}{l}\text { Heart Failure with } \\
\text { Preserved Ejection } \\
\text { Fraction (HFpEF) }\end{array}$} & $\begin{array}{l}216 \text { subjects, } 104 \text { ( } 48 \%) \\
\text { women (RELAX trial) }\end{array}$ & 93 & $\begin{array}{l}\text { No effect on exercise capacity, LVMi, } \\
\text { EDVi, diastolic function, PASP, } \\
\text { mean BP } \\
\downarrow \text { in arterial elastance at CMR. [21] }\end{array}$ \\
\hline & 44 subjects, 9 women. & 7 & $\begin{array}{l}\uparrow \text { cardiac index, E/A ratio, } \mathrm{E}^{\prime} \text {, and } \mathrm{LV} \\
\text { internal dimension; } \\
\downarrow \text { interventricular septum, posterior } \\
\text { wall and relative wall thickness, } \mathrm{LV} \\
\text { mass index, E/E', deceleration time, } \\
\text { and isovolumic relaxation time [22] }\end{array}$ \\
\hline & $\begin{array}{l}59 \text { subjects, all men } \\
\text { (CECSID trial) }\end{array}$ & 59 & $\begin{array}{l}\text { restored coupling in LV contraction: } \\
\downarrow \text { torsion\& } \uparrow \text { strain; } \downarrow \text { concentricity } \\
\text { index }[23]\end{array}$ \\
\hline \multirow{3}{*}{ Myocardial Infarction } & 23 patients, all women & 6 & $\begin{array}{l}\text { Short-term } \uparrow \text { CFR in women after } \\
\text { PDE5i (100 mg) [24] }\end{array}$ \\
\hline & 144 patients, all men & 43 & $\begin{array}{l}\text { Short-term } \uparrow \text { exercise tolerance and } \\
\text { ischemic threshold in men with } \\
\text { CAD and Erectile dysfunction [25] }\end{array}$ \\
\hline & 12 patients, 4 women & N/A & $\uparrow$ safety after ischemic stroke [25] \\
\hline \multirow{4}{*}{ Heart Failure } & 32 patients, all men & $\mathrm{N} / \mathrm{A}$ & $\begin{array}{l}\uparrow \mathrm{HRR}, \mathrm{FMD}, \text { peak } \mathrm{VO}_{2} \\
\downarrow \text { PASP, ergoreflex effect on } \\
\text { ventilation, } \mathrm{V}(\mathrm{E}) / \mathrm{VCO}_{2} \text { slope, } \\
\text { breathlessness score, wedge } \\
\text { pressure, PVR, EOB, DOE [26] }\end{array}$ \\
\hline & 13 patients, 2 women [27] & None & \multirow{3}{*}{$\begin{array}{l}\uparrow \text { oxygen uptake, CI; } \downarrow \text { SVR \& aorta } \\
\text { stiffness; } \uparrow \text { exercise time \& } \downarrow \text { HR } \\
\text { during exercise; } \uparrow \text { 6-min walking } \\
\text { distance; } \uparrow \text { QoL }\end{array}$} \\
\hline & 23 patients, all men [28] & None & \\
\hline & 35 patients, all men [29] & 9 & \\
\hline
\end{tabular}


Table 1. Cont.

\begin{tabular}{|c|c|c|c|}
\hline Condition & Patients & $\begin{array}{l}\text { Patients with } \\
\text { T2DM }(N)\end{array}$ & Main Research Finding \\
\hline & $\begin{array}{l}45 \text { patients, no data about } \\
\text { sex }\end{array}$ & N/A & $\begin{array}{l}\uparrow R V \text { \& LV function, CI, } \\
\text { isovolumetric relaxation, septal } \\
\text { mitral annulus velocity } \\
\downarrow \text { RA pressure, pulmonary fluid } \\
\text { content \& } \uparrow \text { gas conductance } \\
\downarrow \text { LVMi, LAVi, LVEDV, PASP, } \\
\text { NT-proBNP \& } \uparrow \text { QoL [22] }\end{array}$ \\
\hline & 24 patients, all men & None & $\begin{array}{l}\uparrow \text { Pulmonary pressure \& vascular } \\
\text { tone, aerobic \&ventilatory efficiency } \\
\text { oxygen debt [30] }\end{array}$ \\
\hline & 60 patients, all men [31] & N/A & I cardiac sympathetic activity \\
\hline & 10 patients, all men [32] & N/A & \\
\hline & 48 patients, 28 women & 17 & $\begin{array}{l}\text { AT REST: } \downarrow \text { resting central SBP, } \\
\text { trend in } \downarrow \text { of E/A and SVR, no effects } \\
\text { on resting LV systolic-diastolic } \\
\text { function or PASP, tended to increase } \\
\text { endothelial function. } \\
\text { DURING EXERCISE: } \downarrow \text { peak heart } \\
\text { rate; } \uparrow \text { EF and trend toward a less } \\
\text { increase in systolic BP at low level } \\
\text { exercise; } \downarrow \text { of } 11-16 \% \text { LV } \\
\text { contractility. [33] }\end{array}$ \\
\hline \multirow{5}{*}{$\begin{array}{l}\text { Pulmonary Arterial } \\
\text { Hypertension }\end{array}$} & 60 patients, 39 women [34] & N/A & \multirow{2}{*}{$\begin{array}{l}\uparrow \text { cardiac function \& exercise } \\
\text { capacity }\end{array}$} \\
\hline & 26 patients, 21 women [35] & $\mathrm{N} / \mathrm{A}$ & \\
\hline & 13 patients, 10 women & N/A & $\uparrow \mathrm{CO} ; \downarrow$ PASP, PAmP, PVR [36] \\
\hline & 12 patients & $\mathrm{N} / \mathrm{A}$ & pulmonary vasodilation [37] \\
\hline & 277 patients, 209 women & N/A & $\begin{array}{l}\uparrow 6 \text { min WT \& WHO functional } \\
\text { class and } \downarrow \text { PAmP [38] }\end{array}$ \\
\hline $\begin{array}{l}\text { Congenital } \\
\text { Cardiomyopathy }\end{array}$ & $\begin{array}{l}28 \text { subjects, } \\
10(36 \%) \text { women }\end{array}$ & none & $\uparrow$ ventricular performance [39] \\
\hline
\end{tabular}

BP: blood pressure; CAD: Coronary artery disease; CI: cardiac index; CFR: Coronary flow reserve; CMR: cardiac magnetic resonance; CO: cardiac output; DOE: dyspnea upon exertion at peak exercise; EOB: exercise oscillatory breathing; EDVi: end diastolic volume index; EF: ejection fraction; FMD: flow mediated dilation; HR: heart rate; HRR: heart recovery rate; LV: left ventricle; LVEDV: left ventricle end diastolic volume; LVMi: LV mass index; LAVi: Left Atrial Volume index; QoL: quality of life; NT-ProBNP: N-terminal B-type natriuretic peptide; PAmP: pulmonary arterial mean pressure; PASP: pulmonary arterial systolic pressure; PVR: pulmonary vascular resistance; RA: right atria; RV: right ventricle; SVR: systemic vascular resistance; $\mathrm{V}(\mathrm{E}) / \mathrm{VCO}_{2}$ slope: ventilation to $\mathrm{CO}_{2}$ production; $\mathrm{VO}_{2}$ : maximal oxygen consumption; WT: walking test; WHO: World Health Organization; $\uparrow$ increase; $\downarrow$ decrease.

\section{Phosphodiesterase-5 Inhibitors and T2DM-Related Cardiovascular Complications}

National Cholesterol Education Program's Adult Treatment Panel III (ATP III) report defined the criteria used to identify patient with metabolic syndrome: abdominal obesity, high triglycerides, raised plasma glucose, increased blood pressure and low level of HDL [40]. It is well established that subjects who meet these criteria displayed increased risk to develop T2DM over the time. T2DM is also closely linked to overweight and obesity, even if the relationship between obesity and T2DM has not yet fully elucidated [41]. It has been proposed that obesity, changing the body's metabolism, induces an increased release of fatty acids, glycerol, hormones, pro-inflammatory cytokines and other factors from adipose tissue (AT) that are involved into insulin resistance development [42].

White adipose tissue (WAT) produces cytokines such as TNF-alpha, IL-1, IL-6, IL-10, monocyte chemoattractant protein (MCP-1) and leptin, adiponectin, resistin, referred to as adipokines, that are markedly dysregulated in obese patients [43]. This inflammatory state is amplified by macrophages infiltration in adipose tissue, triggering a local and systemic chronic low-grade inflammation, that may interfere with glucose metabolism and insulin sensitivity in T2DM [43]. The increase of 
pro-inflammatory factors and endothelial dysfunction, with a reduction of NO-dependent vasodilation, are interrelated factors in the etiology of both T2DM and cardiovascular disease. In fact, T2DM patients develop heart failure (HF) after ischemia/reperfusion injury (I/R) at more than double the rate of non-diabetics and they have a ten-year lower life expectancy than the average [44,45]. Several studies suggest that PDE5i could improve survival of patient with T2DM. In a retrospective cohort study, Hackett and colleagues found that PDE5i alone or combined with testosterone significantly reduced age-related mortality in men with T2DM [46]; results derived from an observational study in a large cohort of T2DM patients revealed that all cause of mortality rates were lower in patients that received PDE5 inhibitor than those who did not. Anderson et al. [47] also described that, in PDE5 inhibitor users, the rate of incident MI was lower and associate with a lower mortality rate compared to PDE5 inhibitor non-users. PDE5 inhibitors are currently under examination for the treatment of T2DM derangements, endothelial dysfunction and chronic inflammation state, and its complications, as diabetic cardiomyopathy (DCM) and I/R injury. Even if the mechanism by which PDE5 inhibitors can heal such impairments has yet not fully understood, there is encouraging evidence of their use in the treatment of such complications.

\section{Endothelial Dysfunction and Inflammation}

Endothelium is considered an endocrine and paracrine organ able to secrete several biological mediators, and to respond to a variety of neuro-hormonal signals. Among these mediators there are the vasoactive ones, which play a fundamental role in the control of vascular tone of the arteries and microcirculation [48]. Endothelial dysfunction (ED) causes the loss of structural integrity resulting in the disruption of its functionality. ED is considered one of the major complications of T2DM, consisting in a reduced NO-dependent vasodilation. In fact, the generation of NO by the vascular endothelium maintains a continuous vasodilator tone that is essential for the regulation of blood flow and pressure [49]. Due to NO involvement in the reduced vasodilatation that occur in T2DM, PDE5 inhibitors have been proposed to be useful to restore the NO/cGMP/PKG pathway. Beneficial effect of PDE5 inhibition (PDE5i) has been demonstrated in mesenteric arteries from young female rats with T2DM showing an increased sensitivity to sildenafil in terms of relaxation but a reduced responses to NO-dependent and -independent of sGC activation, compared with nondiabetic rats [50]. In human endothelial cells displaying insulin resistance, sildenafil treatment was able to restore NO production activating eNOS and reducing oxidative stress induced by hyperglycemia [51].

In T2DM patients, both acute and chronic daily treatment with sildenafil could exert prolonged beneficial effects on ED without any adverse effects on cardiovascular autonomic nerve function such as orthostatic blood pressure regulation [52]. In fact, in a double-blind placebo-controlled trial, flow-mediated dilatation (FMD), a measure of NO-mediated endothelial function, is significantly improved in PDE5i treated T2DM patients [53]. Similarly, other studies have demonstrated that FMD amelioration, after sildenafil or tadalafil treatment, was accompanied with an increase in nitrite/nitrate levels together with an improvement of vascular inflammation markers and with a concomitant decrease in endothelin-1 (ET1) [54-57]. A meta-analysis on randomized clinical trials in which T2DM patients were chronically treated with PDE5i suggests a beneficial effect on endothelium with an overall improvement of hemodynamic and inflammation-related parameters [58]. Another study confirms the positive effect of sildenafil treatment on glucometabolic control in T2DM patients with a reduction of the endothelial function marker P-selectin [59]. In this context, PDE5i treatment was indeed associated with a significant reduction of albuminuria and glycated hemoglobin ( $\mathrm{HbA1c}$ [60]. It is worth noticed that, some years later, a meta-analysis on the effect of PDE5i on glycemic control in T2DM concluded that PDE5i had no beneficial effect on $\mathrm{HbA1c}$ [61], similar results were obtained in diabetic mice, where the authors did not observed changes in blood glucose or insulin levels upon chronic inhibition of PDE5 [62].

As mentioned above, T2DM is associated not only with endothelial impairments, but also with an increased production of pro-inflammatory factors that together with endothelial disruption can lead to 
an increased risk of long-term cardio-metabolic disease [63]. Several studies have demonstrated that PDE5i displays cardioprotective effects in T2DM, reducing levels of circulating inflammatory cytokines therefore exerting an anti-inflammatory response $[58,59,64]$, protecting against tissue damages and preserving endothelial cell functions [65].

Obesity is characterized by an impairment of adipocyte functions such as the expression of adipokines, as well as a chronic inflammation state which determine an uncontrolled expansion of AT depots that are associated with multiple metabolic risks. In $d b / d b$ mice, sildenafil induced an overall reduction in AT, mainly in visceral AT (VAT) associated with a reduction in cytokines expression. Stromal vascular fraction (SVF) of subcutaneous adipose tissue (SAT) showed an increase in the frequency of anti-inflammatory M2 macrophages and endothelial cells in treated mice that leads to an improvement of SAT homeostasis and distribution [62] confirming an interconnection between inflammation and endothelium.

Tyrosine kinase receptors (TKRs), in concert with angiopoietins and VEGF signaling, are key regulators of vessel integrity and architecture. Among angiopoietins, Angiopoietin-1 (Ang1) and Angiopoietin-2 (Ang2) contribute to neovascularization and vascular homeostasis. Ang1 and its competitor Ang2 bind to the common endothelial TKR, the endothelium-specific receptor tyrosine kinase 2 (Tie2). While Ang1 acts as agonist of Tie2 through the induction of autophosphorylation of the receptor which is mandatory to maintain blood vessels integrity, Ang2 competes with Ang1 for Tie2 binding, thereby exerting an inhibitory function on Ang1/Tie2 signaling [66]. There is emerging evidence that an imbalance of the Ang2/Ang1 ratio could contribute to micro- and macro-vascular complications observable in T2DM [67]. Beside the endothelium, Tie2 receptor is also expressed by a unique subset of monocytes, Tie2-expressing monocytes (TEMs), which have been considered crucial for tissue remodeling and repair $[59,68]$. Interestingly, TEMs and Ang1 are defective in $d b / d b$ male mice and in T2DM patients [69]. Chronic PDE5i has been shown to restore the angiogenic capacity via Ang1-Tie2 pathway, normalizing the frequency of circulating pro-inflammatory monocytes [70].

In a T2DM mouse model, tadalafil treatment lowers the inflammation grade by decreasing levels of circulating inflammatory markers, such as TNF- $\alpha$ and interleukin 1 beta (IL-1 $\beta$ ) [64]. A similar improvement was observable in the serum of patients with DCM where chronic sildenafil treatment reduces Interleukin 8 (IL-8) and CXCL10 levels. PDE5i display an analogous capability in cultured human cardiac, endothelial and immune cells under inflammatory stimuli. In these cells, pharmacological inhibition of PDE5 is able to interfere with IL-8 release from endothelial cells and to reduce IL-8 mRNA expression levels in peripheral mononuclear cells together with a downregulation of CXCL10 secretion from cardiomyocytes. The reduction of the vascular inflammation marker IL-6, in T2DM sildenafil-treated patients, was also reported [54]. This observation was confirmed later on by a meta-analysis on available Randomized Clinical Trials [58].

\section{PDE5 Inhibitors and Diabetic Cardiomyopathy}

DCM is defined by the existence of altered myocardial architecture and performance in the absence of other cardiac risk factors, such as coronary artery disease (CAD), and hypertension, in individuals affected by diabetes mellitus [71]. In diabetes, heart failure (HF) is triggered by a combination of systemic metabolic disorders (hyperglycemia, hyperinsulinemia, insulin resistance), oxidative stress, inflammation and endothelial dysfunction [72]. The early stage of diabetic DCM is characterized by an initial asymptomatic phase characterized by a reduction of diastolic filling and elevated left ventricular end-diastolic pressure (LVEDP) and a second phase in which clinical manifestations occur. It can evolve in cardiac remodeling, left ventricular (LV) hypertrophy, even with normal ejection fraction and protracted isovolumetric relaxation. DCM can progress into systolic dysfunction leading to LV dilation and, finally, HF. Cardiomyocytes apoptosis, the stiffening and hypertrophy of surrounding myocytes, and the establishment of interstitial and perivascular fibrosis contribute to the derangement of heart architecture [71]. 
The impairment of NO bioavailability and the subsequent endothelial dysfunction play a pivotal role in the establishment of cardiac disorder in T2DM patients. Given these premises and the powerful cardioprotective effects of PDE5i in HF mouse models $[18,19]$, in the last decade, pharmacological inhibition of PDE5 has been evaluated as a potential treatment to induce cardiac remodeling in T2DM. In $d b / d b$ mice, tadalafil treatment reverses the alterations of cytoskeletal/contractile proteins, restores redox signaling [73] and, activating NO-induced SIRT1-PGC- $1 \alpha$ signaling, attenuates mitochondrial dysfunction [74]. Tadalafil treatment is able to reduce infarct size induced by $\mathrm{I} / \mathrm{R}$ in hearts isolated from mice with cardiomyocytes displaying a lower rate of apoptosis and necrosis [64]. In diabetic rats with preserved ejection fraction (HFpEF), vardenafil was effective in the maintenance of diastolic function, reduction of myocardial hypertrophy and induction of fibrotic remodeling, via the cGMP-PKG pathway. This action passes through a lowering of apoptosis and a reduction of nitro-oxidative stress [75]. A higher expression of the lncRNA Metastasis-Associated Lung Adenocarcinoma Transcript 1 (MALAT1) has been observed in DCM [76]. Sildenafil counteracts this increase in cardiomyocytes exposed to elevated glucose levels in vitro and in vivo revealing a new molecular pathway that correlates the transcription of IncRNAs and sildenafil-induced amelioration of cardiomyopathy associated with dysmetabolic conditions including diabetes [77]. Recently, the molecular mechanism underling the improvement of contractility observed in cardiomyocytes isolated from sildenafil-treated mice under high-fat diet (HFD) was elucidated. In diabetic hearts, sildenafil treatment improved "cardiac reserve" in response to sympathetic stimulation in a $\beta 2$-adrenergic receptor ( $\beta 2 \mathrm{AR}$ )-dependent fashion, by enhancing cGMP-PKG signaling, as well as phosphodiesterase 3-dependent cAMP signaling, ameliorating overall the excitation-contraction (E-C) coupling [78]. The reciprocal interaction between PDE5 and $\beta 2 A R$ characterizes a new functional axis ( $\beta 2 A R-P D E 5)$ through which sildenafil can improve DCM symptoms. In T2DM patients, the improvement in cardiac performance has been demonstrated by several clinical trials [22,23]; however, in the RELAX trial, authors showed that sildenafil has few effects on HF [79], a statement that does not take account the fact that half of the patients enrolled in this trial were female, underestimating gender differences (Table 1). More efforts have to be put in the elucidation of sex-specific effects and molecular pathway of PDE5i: preclinical studies and clinical studies should be carefully planned to fully clarify the benefits of PDE5 inhibitors in cardiovascular disease. This issue is particularly important since it was demonstrated that the therapeutic efficacy of PDE5i is estrogen-dependent in pressure overload-induced hypertrophic female mouse hearts [80].

A large body of evidence has proved the utility of PDE5 inhibitors in the treatment of $I / R$, in T2DM hearts, both in animal model and humans. The administration of sildenafil or vardenafil produces both acute and durable cardio-protective effects in rabbits [81]. Tadalafil treatment leads to augmented hydrogen sulfide (H2S) that, in the last years, emerged as a PKG effector with important cardioprotective effects [20,82]. PDE5 inhibitors protect the heart acting on cGMP/PKG pathway, up-regulating both eNOS and H2S expression levels $[83,84]$. In addition, PDE5 inhibition phosphorylates extracellular signal-regulated kinase (ERK), which in turn inhibits the phosphorylation of Glycogen Synthase Kinase-3 $\beta$ (GSK-3 $\beta$ ) [85]. This inhibition activates a wide spectrum of cardioprotective signaling effectors, such as Adenine Nucleotide Translocator (ANT) and Cyclophilin D (CyP-D) [86]

\section{Conclusions}

Even though PDE5 inhibitors achieved a great initial success for erectile dysfunction, nowadays it is clear that they have favourable systemic effects behind the sexual one. T2DM is characterised by hyperglycaemia, insulin resistance and dyslipidaemia. These pro-inflammatory states result in an increase of oxidative stress and a reduced NO production that generate a progressive endothelial dysfunction, hypertension and increases cardiovascular risk. Macro- and micro-vascular complications and inflammation result ameliorated after pharmacological inhibition of PDE5 that is largely attributable to the restoration of the NO-cGMP-PKG signalling pathway (Figure 1). 


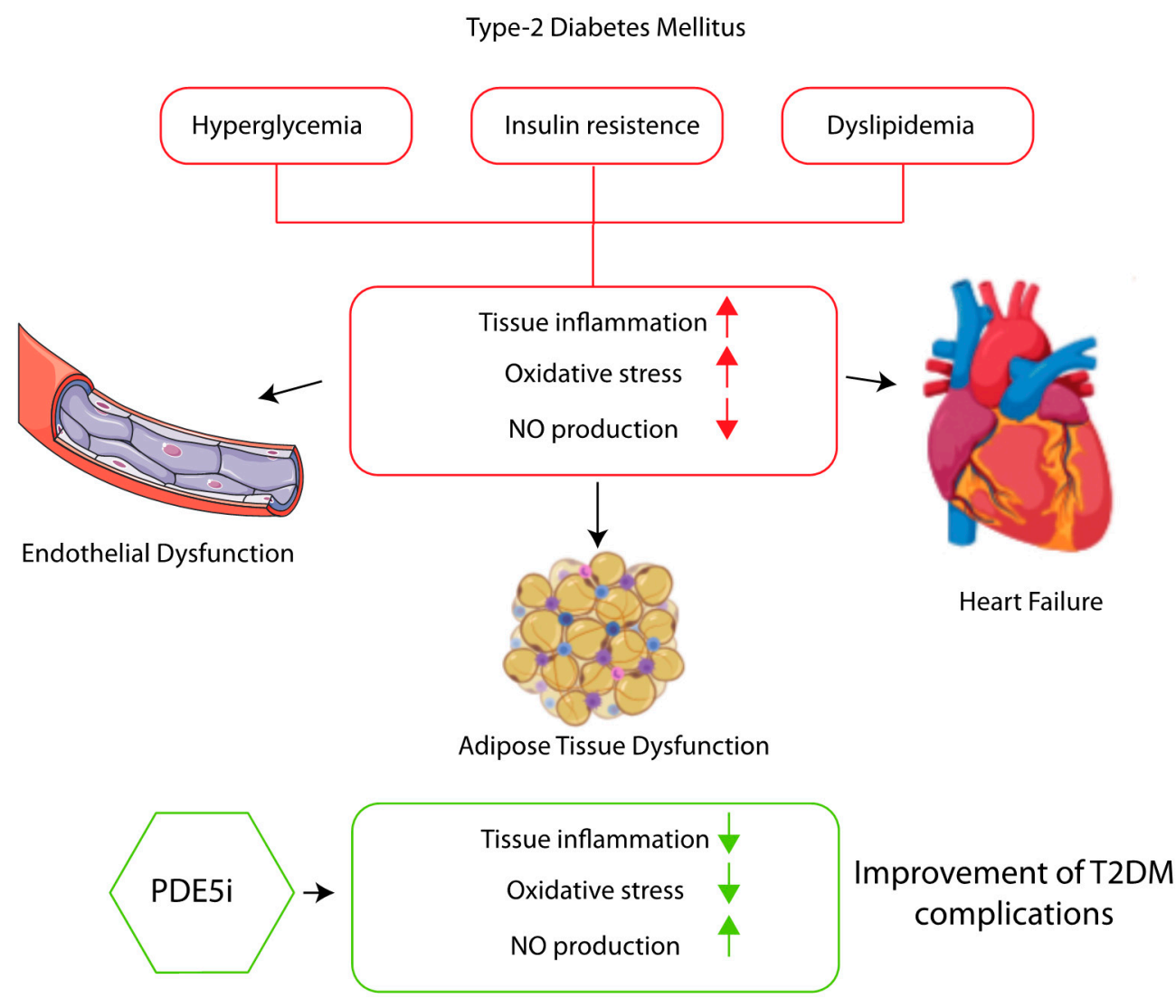

Figure 1. PDE5I improves endothelial and adipose tissue dysfunction, and cardiovascular disease associated with type 2 diabetes reducing tissue inflammation, ameliorating oxidative stress trough NO-cGMP-PKG pathway activation.

Author Contributions: F.B., F.C., E.F., E.C. writing-original draft preparation, R.P., A.M.I. and M.A.V. writing-review and editing. All authors have read and agreed to the published version of the manuscript.

Funding: This research was funded by Sapienza Ricerca ATENEO 2019, grant number RG11916B8889B100.

Conflicts of Interest: A.M.I. received consultation fees, unconditional grants, and hospitality to conferences from IBSA, Takeda, and IPSEN. The other authors have nothing to disclose.

\section{References}

1. Baillie, G.S.; Tejeda, G.S.; Kelly, M.P. Therapeutic targeting of 3' $5^{\prime}$-cyclic nucleotide phosphodiesterases: Inhibition and beyond. Nat. Rev. Drug Discov. 2019, 18, 770-796. [CrossRef] [PubMed]

2. Maurice, D.H.; Ke, H.; Ahmad, F.; Wang, Y.; Chung, J.; Manganiello, V.C. Advances in targeting cyclic nucleotide phosphodiesterases. Nat. Rev. Drug Discov. 2014, 13, 290-314. [CrossRef] [PubMed]

3. Isidori, A.M.; Cornacchione, M.; Barbagallo, F.; Di Grazia, A.; Barrios, F.; Fassina, L.; Monaco, L.; Giannetta, E.; Gianfrilli, D.; Garofalo, S.; et al. Inhibition of type 5 phosphodiesterase counteracts $\beta 2$-adrenergic signalling in beating cardiomyocytes. Cardiovasc. Res. 2015, 106. [CrossRef] [PubMed]

4. Butt, E.; Abel, K.; Krieger, M.; Palm, D.; Hoppe, V.; Hoppe, J.; Walter, U. cAMP- and cGMP-dependent protein kinase phosphorylation sites of the focal adhesion vasodilator-stimulated phosphoprotein (VASP) in vitro and in intact human platelets. J. Biol. Chem. 1994, 269, 14509-14517.

5. Surks, H.K. Regulation of Myosin Phosphatase by a Specific Interaction with cGMP- Dependent Protein Kinase I. Science (80-.) 1999, 286, 1583-1587. [CrossRef]

6. Fukao, M.; Mason, H.S.; Britton, F.C.; Kenyon, J.L.; Horowitz, B.; Keef, K.D. Cyclic GMP-dependent Protein Kinase Activates Cloned BK Ca Channels Expressed in Mammalian Cells by Direct Phosphorylation at Serine 1072. J. Biol. Chem. 1999, 274, 10927-10935. [CrossRef] [PubMed] 
7. Schlossmann, J.; Ammendola, A.; Ashman, K.; Zong, X.; Huber, A.; Neubauer, G.; Wang, G.-X.; Allescher, H.-D.; Korth, M.; Wilm, M.; et al. Regulation of intracellular calcium by a signalling complex of IRAG, IP3 receptor and cGMP kinase I $\beta$. Nature 2000, 404, 197-201. [CrossRef] [PubMed]

8. Forte, M.; Madonna, M.; Schiavon, S.; Valenti, V.; Versaci, F.; Biondi Zoccai, G.; Frati, G.; Sciarretta, S. Cardiovascular Pleiotropic Effects of Natriuretic Peptides. Int. J. Mol. Sci. 2019, 20, 3874. [CrossRef]

9. Bork, N.I.; Molina, C.E.; Nikolaev, V.O. cGMP signalling in cardiomyocyte microdomains. Biochem. Soc. Trans. 2019, 47, 1327-1339. [CrossRef]

10. Campolo, F.; Zevini, A.; Cardarelli, S.; Monaco, L.; Barbagallo, F.; Pellegrini, M.; Cornacchione, M.; Di Grazia, A.; De Arcangelis, V.; Gianfrilli, D.; et al. Identification of murine phosphodiesterase 5A isoforms and their functional characterization in HL-1 cardiac cell line. J. Cell. Physiol. 2018, 233. [CrossRef]

11. Lin, C.-S. Tissue expression, distribution, and regulation of PDE5. Int. J. Impot. Res. 2004, 16, S8-S10. [CrossRef]

12. Cesarini, V.; Guida, E.; Campolo, F.; Crescioli, C.; Di Baldassarre, A.; Pisano, C.; Balistreri, C.R.; Ruvolo, G.; Jannini, E.A.; Dolci, S. Type 5 phosphodiesterase (PDE5) and the vascular tree: From embryogenesis to aging and disease. Mech. Ageing Dev. 2020, 190, 111311. [CrossRef]

13. Jannini, E.A.; Droupy, S. Needs and Expectations of Patients with Erectile Dysfunction: An Update on Pharmacological Innovations in Phosphodiesterase Type 5 Inhibition with Focus on Sildenafil. Sex Med. 2019, 7, 1-10. [CrossRef]

14. Zhang, M.; Koitabashi, N.; Nagayama, T.; Rambaran, R.; Feng, N.; Takimoto, E.; Koenke, T.; O’Rourke, B.; Champion, H.C.; Crow, M.T.; et al. Expression, activity, and pro-hypertrophic effects of PDE5A in cardiac myocytes. Cell Signal. 2008, 20, 2231-2236. [CrossRef] [PubMed]

15. Degen, C.V.; Bishu, K.; Zakeri, R.; Ogut, O.; Redfield, M.M.; Brozovich, F.V. The Emperor's New Clothes: PDE5 and the Heart. PLOS ONE 2015, 10, e0118664. [CrossRef]

16. Shan, X.; Quaile, M.P.; Monk, J.K.; French, B.; Cappola, T.P.; Margulies, K.B. Differential Expression of PDE5 in Failing and Nonfailing Human Myocardium. Circ. Heart Fail. 2012, 5, 79-86. [CrossRef] [PubMed]

17. Vandeput, F.; Krall, J.; Ockaili, R.; Salloum, F.N.; Florio, V.; Corbin, J.D.; Francis, S.H.; Kukreja, R.C.; Movsesian, M.A. cGMP-Hydrolytic Activity and Its Inhibition by Sildenafil in Normal and Failing Human and Mouse Myocardium. J. Pharmacol. Exp. Ther. 2009, 330, 884-891. [CrossRef]

18. Takimoto, E.; Champion, H.C.; Li, M.; Belardi, D.; Ren, S.; Rodriguez, E.R.; Bedja, D.; Gabrielson, K.L.; Wang, Y.; Kass, D.A. Chronic inhibition of cyclic GMP phosphodiesterase 5A prevents and reverses cardiac hypertrophy. Nat. Med. 2005, 11, 214-222. [CrossRef]

19. Fisher, P.W.; Salloum, F.; Das, A.; Hyder, H.; Kukreja, R.C. Phosphodiesterase-5 Inhibition With Sildenafil Attenuates Cardiomyocyte Apoptosis and Left Ventricular Dysfunction in a Chronic Model of Doxorubicin Cardiotoxicity. Circulation 2005, 111, 1601-1610. [CrossRef] [PubMed]

20. Salloum, F.N.; Chau, V.Q.; Hoke, N.N.; Abbate, A.; Varma, A.; Ockaili, R.A.; Toldo, S.; Kukreja, R.C. Phosphodiesterase-5 Inhibitor, Tadalafil, Protects Against Myocardial Ischemia/Reperfusion Through Protein-Kinase G-Dependent Generation of Hydrogen Sulfide. Circulation 2009, 120, S31-S36. [CrossRef]

21. Redfield, M.M.; Chen, H.H.; Borlaug, B.A.; Semigran, M.J.; Lee, K.L.; Lewis, G.; LeWinter, M.M.; Rouleau, J.L.; Bull, D.A.; Mann, D.L.; et al. Effect of Phosphodiesterase-5 Inhibition on Exercise Capacity and Clinical Status in Heart Failure with Preserved Ejection Fraction. JAMA 2013, 309, 1268. [CrossRef] [PubMed]

22. Guazzi, M.; Vicenzi, M.; Arena, R.; Guazzi, M.D. PDE5 Inhibition with Sildenafil Improves Left Ventricular Diastolic Function, Cardiac Geometry, and Clinical Status in Patients with Stable Systolic Heart Failure. Circ. Heart Fail. 2011, 4, 8-17. [CrossRef] [PubMed]

23. Giannetta, E.; Isidori, A.M.; Galea, N.; Carbone, I.; Mandosi, E.; Vizza, C.D.; Naro, F.; Morano, S.; Fedele, F.; Lenzi, A. Chronic Inhibition of cGMP Phosphodiesterase 5A Improves Diabetic Cardiomyopathy. Circulation 2012, 125, 2323-2333. [CrossRef] [PubMed]

24. Denardo, S.J.; Wen, X.; Handberg, E.M.; Bairey Merz, C.N.; Sopko, G.S.; Cooper-DeHoff, R.M.; Pepine, C.J. Effect of Phosphodiesterase Type 5 Inhibition on Microvascular Coronary Dysfunction in Women: A Women's Ischemia Syndrome Evaluation (WISE) Ancillary Study. Clin. Cardiol. 2011, 34, 483-487. [CrossRef] [PubMed]

25. Fox, K. Sildenafil citrate does not reduce exercise tolerance in men with erectile dysfunction and chronic stable angina. Eur. Heart J. 2003, 24, 2206-2212. [CrossRef] [PubMed] 
26. Guazzi, M.; Vicenzi, M.; Arena, R. Phosphodiesterase 5 inhibition with sildenafil reverses exercise oscillatory breathing in chronic heart failure: A long-term cardiopulmonary exercise testing placebo-controlled study. Eur. J. Heart Fail. 2012, 14, 82-90. [CrossRef]

27. Lewis, G.D.; Lachmann, J.; Camuso, J.; Lepore, J.J.; Shin, J.; Martinovic, M.E.; Systrom, D.M.; Bloch, K.D.; Semigran, M.J. Sildenafil Improves Exercise Hemodynamics and Oxygen Uptake in Patients With Systolic Heart Failure. Circulation 2007, 115, 59-66. [CrossRef]

28. Bocchi, E.A.; Guimarães, G.; Mocelin, A.; Bacal, F.; Bellotti, G.; Ramires, J.F. Sildenafil Effects on Exercise, Neurohormonal Activation, and Erectile Dysfunction in Congestive Heart Failure. Circulation 2002, 106, 1097-1103. [CrossRef]

29. Webster, L.J.; Michelakis, E.D.; Davis, T.; Archer, S.L. Use of Sildenafil for Safe Improvement of Erectile Function and Quality of Life in Men With New York Heart Association Classes II and III Congestive Heart Failure. Arch. Intern. Med. 2004, 164, 514. [CrossRef]

30. Guazzi, M.; Tumminello, G.; Di Marco, F.; Fiorentini, C.; Guazzi, M.D. The effects of phosphodiesterase-5 inhibition with sildenafil on pulmonary hemodynamics and diffusion capacity, exercise ventilatory efficiency, and oxygen uptake kinetics in chronic heart failure. J. Am. Coll. Cardiol. 2004, 44, 2339-2348. [CrossRef]

31. Al-Hesayen, A.; Floras, J.S.; Parker, J.D. The effects of intravenous sildenafil on hemodynamics and cardiac sympathetic activity in chronic human heart failure. Eur. J. Heart Fail. 2006, 8, 864-868. [CrossRef] [PubMed]

32. Kaye, D.M.; Lefkovits, J.; Jennings, G.L.; Bergin, P.; Broughton, A.; Esler, M.D. Adverse consequences of high sympathetic nervous activity in the failing human heart. J. Am. Coll. Cardiol. 1995, 26, 1257-1263. [CrossRef]

33. Borlaug, B.A.; Lewis, G.D.; McNulty, S.E.; Semigran, M.J.; LeWinter, M.; Chen, H.; Lin, G.; Deswal, A.; Margulies, K.B.; Redfield, M.M. Effects of Sildenafil on Ventricular and Vascular Function in Heart Failure With Preserved Ejection Fraction. Circ. Heart Fail. 2015, 8, 533-541. [CrossRef] [PubMed]

34. Ghofrani, H.A.; Voswinckel, R.; Reichenberger, F.; Olschewski, H.; Haredza, P.; Karadaş, B.; Schermuly, R.T.; Weissmann, N.; Seeger, W.; Grimminger, F. Differences in hemodynamic and oxygenation responses to three different phosphodiesterase-5 inhibitors in patients with pulmonary arterial hypertension. J. Am. Coll. Cardiol. 2004, 44, 1488-1496. [CrossRef]

35. Wilkins, M.R.; Paul, G.A.; Strange, J.W.; Tunariu, N.; Gin-Sing, W.; Banya, W.A.; Westwood, M.A.; Stefanidis, A.; Ng, L.L.; Pennell, D.J.; et al. Sildenafil versus Endothelin Receptor Antagonist for Pulmonary Hypertension (SERAPH) Study. Am. J. Respir. Crit. Care Med. 2005, 171, 1292-1297. [CrossRef]

36. Bhatia, S.; Frantz, R.P.; Severson, C.J.; Durst, L.A.; McGoon, M.D. Immediate and Long-term Hemodynamic and Clinical Effects of Sildenafil in Patients With Pulmonary Arterial Hypertension Receiving Vasodilator Therapy. Mayo Clin. Proc. 2003, 78, 1207-1213. [CrossRef] [PubMed]

37. Schulze-Neick, I. Intravenous Sildenafil Is a Potent Pulmonary Vasodilator in Children With Congenital Heart Disease. Circulation 2003, 108, 167-173. [CrossRef]

38. Galiè, N.; Ghofrani, H.A.; Torbicki, A.; Barst, R.J.; Rubin, L.J.; Badesch, D.; Fleming, T.; Parpia, T.; Burgess, G.; Branzi, A.; et al. Sildenafil Citrate Therapy for Pulmonary Arterial Hypertension. N. Engl. J. Med. 2005, 353, 2148-2157. [CrossRef]

39. Goldberg, D.J.; French, B.; Szwast, A.L.; McBride, M.G.; Marino, B.S.; Mirarchi, N.; Hanna, B.D.; Wernovsky, G.; Paridon, S.M.; Rychik, J. Impact of Sildenafil on Echocardiographic Indices of Myocardial Performance After the Fontan Operation. Pediatr. Cardiol. 2012, 33, 689-696. [CrossRef] [PubMed]

40. Grundy, S.M.; Brewer, H.B.; Cleeman, J.I.; Smith, S.C.; Lenfant, C. Definition of Metabolic Syndrome. Circulation 2004, 109, 433-438. [CrossRef] [PubMed]

41. Pandey, A.; Chawla, S.; Guchhait, P. Type-2 diabetes: Current understanding and future perspectives. IUBMB Life 2015, 67, 506-513. [CrossRef] [PubMed]

42. Kahn, S.E.; Hull, R.L.; Utzschneider, K.M. Mechanisms linking obesity to insulin resistance and type 2 diabetes. Nature 2006, 444, 840-846. [CrossRef] [PubMed]

43. Chait, A.; den Hartigh, L.J. Adipose Tissue Distribution, Inflammation and Its Metabolic Consequences, Including Diabetes and Cardiovascular Disease. Front. Cardiovasc. Med. 2020, 7. [CrossRef]

44. Kenny, H.C.; Abel, E.D. Heart Failure in Type 2 Diabetes Mellitus. Circ. Res. 2019, 124, 121-141. [CrossRef]

45. Lejay, A.; Fang, F.; John, R.; Van, J.A.D.; Barr, M.; Thaveau, F.; Chakfe, N.; Geny, B.; Scholey, J.W. Ischemia reperfusion injury, ischemic conditioning and diabetes mellitus. J. Mol. Cell. Cardiol. 2016, 91, 11-22. [CrossRef] [PubMed] 
46. Hackett, G.; Jones, P.W.; Strange, R.C.; Ramachandran, S. Statin, testosterone and phosphodiesterase 5-inhibitor treatments and age related mortality in diabetes. World J. Diabetes 2017, 8, 104. [CrossRef] [PubMed]

47. Anderson, S.G.; Hutchings, D.C.; Woodward, M.; Rahimi, K.; Rutter, M.K.; Kirby, M.; Hackett, G.; Trafford, A.W.; Heald, A.H. Phosphodiesterase type-5 inhibitor use in type 2 diabetes is associated with a reduction in all-cause mortality. Heart 2016, 102, 1750-1756. [CrossRef]

48. Vanhoutte, P.M.; Mombouli, J.-V. Vascular endothelium: Vasoactive mediators. Prog. Cardiovasc. Dis. 1996, 39, 229-238. [CrossRef]

49. Lyons, D. Impairment and restoration of nitric oxide-dependent vasodilation in cardiovascular disease. Int. J. Cardiol. 1997, 62, S101-S109. [CrossRef]

50. Goulopoulou, S.; Hannan, J.L.; Matsumoto, T.; Ogbi, S.; Ergul, A.; Webb, R.C. Reduced vascular responses to soluble guanylyl cyclase but increased sensitivity to sildenafil in female rats with type 2 diabetes. Am. J. Physiol. Circ. Physiol. 2015, 309, H297-H304. [CrossRef]

51. Mammi, C.; Pastore, D.; Lombardo, M.F.; Ferrelli, F.; Caprio, M.; Consoli, C.; Tesauro, M.; Gatta, L.; Fini, M.; Federici, M.; et al. Sildenafil Reduces Insulin-Resistance in Human Endothelial Cells. PLoS ONE 2011, 6, e14542. [CrossRef]

52. Stirban, A.; Laude, D.; Elghozi, J.-L.; Sander, D.; Agelink, M.W.; Hilz, M.J.; Ziegler, D. Acute effects of sildenafil on flow mediated dilatation and cardiovascular autonomic nerve function in type 2 diabetic patients. Diabetes. Metab. Res. Rev. 2009, 25, 136-143. [CrossRef] [PubMed]

53. Desouza, C.; Parulkar, A.; Lumpkin, D.; Akers, D.; Fonseca, V.A. Acute and Prolonged Effects of Sildenafil on Brachial Artery Flow-Mediated Dilatation in Type 2 Diabetes. Diabetes Care 2002, 25, 1336-1339. [CrossRef]

54. Aversa, A.; Vitale, C.; Volterrani, M.; Fabbri, A.; Spera, G.; Fini, M.; Rosano, G.M.C. Chronic administration of Sildenafil improves markers of endothelial function in men with Type 2 diabetes. Diabet. Med. 2008, 25, 37-44. [CrossRef]

55. Rosano, G.M.C.; Aversa, A.; Vitale, C.; Fabbri, A.; Fini, M.; Spera, G. Chronic Treatment with Tadalafil Improves Endothelial Function in Men with Increased Cardiovascular Risk. Eur. Urol. 2005, 47, $214-222$. [CrossRef] [PubMed]

56. Seftel, A.D. Chronic Treatment With Tadalafil Improves Endothelial Function in Men With Increased Cardiovascular Risk. J. Urol. 2005, 174, 1365. [CrossRef]

57. Roli, L.; Santi, D.; Baraldi, E.; De Santis, M.C.; Trenti, T. Chronic, long term administration of vardenafil improves endothelial function and improves testosterone levels in hypogonadic patients with type 2 diabetes mellitus. Clin. Chem. Lab. Med. 2015. [CrossRef]

58. Santi, D.; Giannetta, E.; Isidori, A.M.; Vitale, C.; Aversa, A.; Simoni, M. THERAPY OF ENDOCRINE DISEASE: Effects of chronic use of phosphodiesterase inhibitors on endothelial markers in type 2 diabetes mellitus: A meta-analysis. Eur. J. Endocrinol. 2015, 172, R103-R114. [CrossRef]

59. Mandosi, E.; Giannetta, E.; Filardi, T.; Lococo, M.; Bertolini, C.; Fallarino, M.; Gianfrilli, D.; Venneri, M.A.; Lenti, L.; Lenzi, A.; et al. Endothelial dysfunction markers as a therapeutic target for Sildenafil treatment and effects on metabolic control in type 2 diabetes. Expert Opin. Ther. Targets 2015, 19, 1617-1622. [CrossRef]

60. Grover-Páez, F.; Villegas Rivera, G.; Guillén Ortíz, R. Sildenafil citrate diminishes microalbuminuria and the percentage of A1c in male patients with type 2 diabetes. Diabetes Res. Clin. Pract. 2007, 78, 136-140. [CrossRef]

61. Poolsup, N.; Suksomboon, N.; Aung, N. Effect of phosphodiesterase-5 inhibitors on glycemic control in person with type 2 diabetes mellitus: A systematic review and meta-analysis. J. Clin. Transl. Endocrinol. 2016, 6, 50-55. [CrossRef]

62. Fiore, D.; Gianfrilli, D.; Cardarelli, S.; Naro, F.; Lenzi, A.; Isidori, A.M.; Venneri, M.A. Chronic phosphodiesterase type 5 inhibition has beneficial effects on subcutaneous adipose tissue plasticity in type 2 diabetic mice. J. Cell. Physiol. 2018, 233, 8411-8417. [CrossRef] [PubMed]

63. Lontchi-Yimagou, E.; Sobngwi, E.; Matsha, T.E.; Kengne, A.P. Diabetes Mellitus and Inflammation. Curr. Diab. Rep. 2013, 13, 435-444. [CrossRef] [PubMed]

64. Varma, A.; Das, A.; Hoke, N.N.; Durrant, D.E.; Salloum, F.N.; Kukreja, R.C. Anti-Inflammatory and Cardioprotective Effects of Tadalafil in Diabetic Mice. PLoS ONE 2012, 7, e45243. [CrossRef] [PubMed] 
65. Pofi, R.; Fiore, D.; De Gaetano, R.; Panio, G.; Gianfrilli, D.; Pozza, C.; Barbagallo, F.; Xiang, Y.K.; Giannakakis, K.; Morano, S.; et al. Phosphodiesterase- 5 inhibition preserves renal hemodynamics and function in mice with diabetic kidney disease by modulating miR-22 and BMP7. Sci. Rep. 2017, 7, 44584. [CrossRef]

66. Akwii, R.G.; Sajib, M.S.; Zahra, F.T.; Mikelis, C.M. Role of Angiopoietin-2 in Vascular Physiology and Pathophysiology. Cells 2019, 8, 471. [CrossRef]

67. Isidori, A.M.; Venneri, M.A.; Fiore, D. Angiopoietin-1 and Angiopoietin-2 in metabolic disorders: Therapeutic strategies to restore the highs and lows of angiogenesis in diabetes. J. Endocrinol. Investig. 2016, 39, 1235-1246. [CrossRef]

68. Venneri, M.A.; De Palma, M.; Ponzoni, M.; Pucci, F.; Scielzo, C.; Zonari, E.; Mazzieri, R.; Doglioni, C.; Naldini, L. Identification of proangiogenic TIE2-expressing monocytes (TEMs) in human peripheral blood and cancer. Blood 2007, 109, 5276-5285. [CrossRef]

69. Rasul, S.; Reiter, M.H.; Ilhan, A.; Lampichler, K.; Wagner, L.; Kautzky-Willer, A. Circulating angiopoietin-2 and soluble Tie-2 in type 2 diabetes mellitus: A cross-sectional study. Cardiovasc. Diabetol. 2011, 10, 55. [CrossRef]

70. Venneri, M.A.; Barbagallo, F.; Fiore, D.; De Gaetano, R.; Giannetta, E.; Sbardella, E.; Pozza, C.; Campolo, F.; Naro, F.; Lenzi, A.; et al. PDE5 Inhibition Stimulates Tie2-Expressing Monocytes and Angiopoietin-1 Restoring Angiogenic Homeostasis in Diabetes. J. Clin. Endocrinol. Metab. 2019, 104, 2623-2636. [CrossRef]

71. Jia, G.; Hill, M.A.; Sowers, J.R. Diabetic Cardiomyopathy. Circ. Res. 2018, 122, 624-638. [CrossRef] [PubMed]

72. Lee, W.-S.; Kim, J. Diabetic cardiomyopathy: Where we are and where we are going. Korean J. Intern. Med. 2017, 32, 404-421. [CrossRef] [PubMed]

73. Koka, S.; Xi, L.; Kukreja, R.C. Chronic treatment with long acting phosphodiesterase-5 inhibitor tadalafil alters proteomic changes associated with cytoskeletal rearrangement and redox regulation in Type 2 diabetic hearts. Basic Res. Cardiol. 2012, 107, 249. [CrossRef] [PubMed]

74. Koka, S.; Aluri, H.S.; Xi, L.; Lesnefsky, E.J.; Kukreja, R.C. Chronic inhibition of phosphodiesterase 5 with tadalafil attenuates mitochondrial dysfunction in type 2 diabetic hearts: Potential role of NO/SIRT1/PGC- $1 \alpha$ signaling. Am. J. Physiol. Circ. Physiol. 2014, 306, H1558-H1568. [CrossRef]

75. Mátyás, C.; Németh, B.T.; Oláh, A.; Török, M.; Ruppert, M.; Kellermayer, D.; Barta, B.A.; Szabó, G.; Kökény, G.; Horváth, E.M.; et al. Prevention of the development of heart failure with preserved ejection fraction by the phosphodiesterase-5A inhibitor vardenafil in rats with type 2 diabetes. Eur. J. Heart Fail. 2017, 19, 326-336. [CrossRef]

76. Zhang, M.; Gu, H.; Chen, J.; Zhou, X. Involvement of long noncoding RNA MALAT1 in the pathogenesis of diabetic cardiomyopathy. Int. J. Cardiol. 2016, 202, 753-755. [CrossRef]

77. Bacci, L.; Barbati, S.A.; Colussi, C.; Aiello, A.; Isidori, A.M.; Grassi, C.; Pontecorvi, A.; Farsetti, A.; Gaetano, C.; Nanni, S. Sildenafil normalizes MALAT1 level in diabetic cardiomyopathy. Endocrine 2018, 62, 259-262. [CrossRef]

78. West, T.M.; Wang, Q.; Deng, B.; Zhang, Y.; Barbagallo, F.; Reddy, G.R.; Chen, D.; Phan, K.S.; Xu, B.; Isidori, A.; et al. Phosphodiesterase 5 Associates With $\beta 2$ Adrenergic Receptor to Modulate Cardiac Function in Type 2 Diabetic Hearts. J. Am. Heart Assoc. 2019, 8. [CrossRef]

79. Wang, H.; Anstrom, K.; Ilkayeva, O.; Muehlbauer, M.J.; Bain, J.R.; McNulty, S.; Newgard, C.B.; Kraus, W.E.; Hernandez, A.; Felker, G.M.; et al. Sildenafil Treatment in Heart Failure With Preserved Ejection Fraction. JAMA Cardiol. 2017, 2, 896. [CrossRef]

80. Sasaki, H.; Nagayama, T.; Blanton, R.M.; Seo, K.; Zhang, M.; Zhu, G.; Lee, D.I.; Bedja, D.; Hsu, S.; Tsukamoto, O.; et al. PDE5 inhibitor efficacy is estrogen dependent in female heart disease. J. Clin. Investig. 2014, 124, 2464-2471. [CrossRef]

81. Ockaili, R.; Salloum, F.; Hawkins, J.; Kukreja, R.C. Sildenafil (Viagra) induces powerful cardioprotective effect via opening of mitochondrial K ATP channels in rabbits. Am. J. Physiol. Circ. Physiol. 2002, 283, H1263-H1269. [CrossRef] [PubMed]

82. Andreadou, I.; Iliodromitis, E.K.; Szabo, C.; Papapetropoulos, A. Hydrogen sulfide and PKG in ischemia-reperfusion injury: Sources, signaling, accelerators and brakes. Basic Res. Cardiol. 2015, 110, 52. [CrossRef] [PubMed]

83. Miura, T.; Miki, T. GSK-3ß, a Therapeutic Target for Cardiomyocyte Protection. Circ. J. 2009, 73, $1184-1192$. [CrossRef] [PubMed] 
84. Das, A.; Xi, L.; Kukreja, R.C. Protein Kinase G-dependent Cardioprotective Mechanism of Phosphodiesterase-5 Inhibition Involves Phosphorylation of ERK and GSK3ß. J. Biol. Chem. 2008, 283, 29572-29585. [CrossRef]

85. Das, A.; Xi, L.; Kukreja, R.C. Phosphodiesterase-5 Inhibitor Sildenafil Preconditions Adult Cardiac Myocytes against Necrosis and Apoptosis. J. Biol. Chem. 2005, 280, 12944-12955. [CrossRef]

86. Juhaszova, M.; Zorov, D.B.; Yaniv, Y.; Nuss, H.B.; Wang, S.; Sollott, S.J. Role of Glycogen Synthase Kinase-3 $\beta$ in Cardioprotection. Circ. Res. 2009, 104, 1240-1252. [CrossRef]

Publisher's Note: MDPI stays neutral with regard to jurisdictional claims in published maps and institutional affiliations.

(C) 2020 by the authors. Licensee MDPI, Basel, Switzerland. This article is an open access article distributed under the terms and conditions of the Creative Commons Attribution (CC BY) license (http://creativecommons.org/licenses/by/4.0/). 